\title{
Mineralogical effects of alteration and weathering in peralkaline silicate hosted REE-HFSE deposits
}

\author{
DR. ANOUK M BORST, PHD ${ }^{1,2,3}$, ADRIAN A FINCH ${ }^{4}$, \\ NICOLA HORSBURGH ${ }^{1}$, MARTIN SMITH ${ }^{5}$ AND \\ KALOTINA GERAKI ${ }^{6}$ \\ ${ }^{1}$ University of St Andrews \\ ${ }^{2}$ KU Leuven \\ ${ }^{3}$ Royal Museum for Central Africa \\ ${ }^{4}$ University of St. Andrews \\ ${ }^{5}$ University of Brighton \\ ${ }^{6}$ Diamond Light Source \\ Presenting Author: anoukborst@gmail.com
}

Peralkaline silicate complexes provide important resources for high field strength elements (HFSE) including the rare earth elements (REE), $\mathrm{Zr}, \mathrm{Ti}, \mathrm{Hf}, \mathrm{Nb}$ and $\mathrm{Ta}$. These deposits are some of the mineralogically most diverse and complex resources on the planet. The metals of interest are commonly hosted in a variety of ore minerals, often finely intergrown and each potentially requiring different methods of extraction. This mineralogical diversity is seen within and between deposits of similar petrogenetic origin and presents a significant hurdle in bringing new exploration projects into production as each project requires detailed mineralogical characterisation and metallurgical testing.

Peralkaline magmas are the product of low degree partial melting of enriched lithospheric mantle sources followed by extensive fractional crystallisation. These melts are often enriched in volatiles $\left(\mathrm{OH}, \mathrm{CO}_{2}, \mathrm{~F}, \mathrm{Cl}\right)$, which exsolve into aqueous halogen-rich fluids at the final stages of crystallisation. These fluids can lead to widespread alteration of the primary HFSE-REE minerals, forming fine-grained intergrowths, or pseudomorphs, of secondary REE-HFSE phases $[1,2]$. In certain climates, surface weathering may further break down primary and secondary minerals to form lateritic or ion adsorption type deposits from which metals may be extracted more easily $[3,4]$.

Here we present recent advances in microscale studies of peralkaline silicate-hosted REE-HFSE deposits. This includes synchrotron-based X-ray Absorption Spectroscopy (XAS) and SXRF element mapping to study mineral-scale distribution of REE-HFSE between altered and weathered mineral phases, focusing dominantly on assemblages associated with eudialyte, using examples from Greenland and Madagascar [1,2,3]. We measured X-ray absorption spectra for $\mathrm{Y}$ and $\mathrm{Nd}$ to determine the coordination and site occupation of REE in primary, secondary and supergene mineral phases [4,5]. We will discuss the effects of late-magmatic alteration as well as supergene weathering and possible implications for extraction and processing.

[1] Borst AM et al. (2016) Mineralogical Magazine, 80, 5-30

[2] Van de Ven et al (2019) Minerals 9(7), 422, 1-23

[3] Estrade et al 2019, Ore Geol Reviews 112, 1-21

[4] Borst et al (2020) Nature Communications 11, 1-15

[5] Borst et al (2019) Mineralogical Magazine 84(1), 19-34 